\title{
Locating the Boundaries of the Nuclear North: Arctic Biology, Contaminated Caribou, and the Problem of the Threshold
}

\author{
Jonathan Luedee ${ }^{1}$ (D)
}

Accepted: 2 February 2021 / Published online: 5 March 2021

(c) The Author(s), under exclusive licence to Springer Nature B.V. part of Springer Nature 2021

\begin{abstract}
This essay is a historical-geographical account of how scientists and public health officials conceptualized and assessed northern radioactive exposures in the late 1950s and 1960s. The detection of radionuclides in caribou bodies in northern Canada both demonstrated the global reach of nuclear fallout and revealed the unevenness of toxic relations and radioactive exposures. Following the documentation of the lichen-caribou-human pathway of exposure, Canadian public health officials became increasingly concerned about the possibility of heightened radioactive exposures among Indigenous northerners. Between 1963 and 1969, scientists and officials with Canada's Radiation Protection Division (RPD) coordinated an interdepartmental monitoring program through which they sought to determine whether the consumption of contaminated caribou meat had caused radioactive exposure levels in northern communities to exceed the officially recognized "safe limits." In 1969, the northern monitoring program was suspended after officials determined that radionuclide body burdens had not exceeded the threshold for radioactive exposures. While the RPD emphasized its development of a technoscientific approach to measuring radioactive body burdens, the legitimacy of the monitoring program was linked directly to interdepartmental relations within Canada's colonial northern administration. I situate the northern monitoring program within broader shifts in public health approaches to radiation protection and use Gabrielle Hecht's concept of nuclearity to demonstrate how RPD officials employed the logic of the threshold in their assessment of radioactive exposures.
\end{abstract}

Keywords Radioactive exposures $\cdot$ Nuclearity $\cdot$ Caribou $\cdot$ Historical geography of northern science $\cdot$ Lichen $\cdot$ Contaminants $\cdot$ Nuclear history $\cdot$ Northern Canada

Jonathan Luedee

jonathan.luedee@gmail.com

1 Department of History, University of Toronto, 100 St. George Street, Toronto, ON M5S 3G3, Canada 


\section{Introduction: A New "Caribou Problem" in the North?}

In 1962, William Pruitt, a "specialist in the ecology of northern mammals" and former associate professor of biology at the University of Alaska-Fairbanks (UAF), described what he viewed as the emergence of a new caribou problem in northern Canada (Pruitt 1962, p. 24). While biologists had struggled for years to determine the cause of ongoing population declines among Canada's barren-ground caribou herds, he argued that the new problem was tied directly to the ecological transformations unleashed since the onset of the atomic age. After more than a decade of atmospheric nuclear testing, barren-ground caribou, he wrote, had been transformed into "hot spots" of radioactive contamination (1962, p. 24). For Pruitt, the discovery of radionuclides in caribou bodies represented a "neat demonstration of the interdependence of all living things" and signaled the vulnerability of northern communities to radioactive contamination (1962, p. 25). Since people consumed caribou throughout the Arctic, Pruitt suggested that the entire northern food chain might have been contaminated. "Behind all the reassuring announcements and news releases about nuclear explosions since the beginning of the Atomic Age," Pruitt warned, "there has lurked the spectre of the time when the so-called 'safe limits' would be exceeded. It is clear that for a great area of the earth's surface that time has now come" (1962, p. 25).

The question posed, however, was whether the emergence of this new caribou problem caused radioactive exposure levels to exceed the officially recognized "safe limits" in communities throughout northern Canada. Pruitt's assertion, which was based mainly on the ecologist's past research in northern Alaska, heightened concerns among federal bureaucrats and public health officials in Canada and revealed a significant geographical lacuna in the federal government's knowledge of radioactive exposures. Although the government had initiated a nationwide fallout monitoring program in the mid-1950s, public health officials acknowledged that studies of radioactive contamination in the food chain had focused on more populated southern regions of the country (Bird 1964a, p. 1029). ${ }^{1}$ To address this critical gap, the Radiation Protection Division (RPD) of the Department of National Health and Welfare (DNHW) initiated a northern monitoring program in 1963, which involved collaborative arrangements among multiple government agencies and members of the country's northern administration. Over the next 6 years, participants in this monitoring program collected and analyzed biological samples from animal and human bodies, conducted experimental human radiation studies, and deployed specialized sensing technologies designed to detect and measure radionuclide "body burdens" (Bird 1964c; Tracy et al. 1997). Through the development and coordination of this monitoring program, the RPD sought to assess the geographic distribution of environmental radioactivity while determining if the resulting radioactive exposures had indeed exceeded the "so-called "safe limits."

\footnotetext{
${ }^{1}$ Library Archives Canada (hereafter cited as LAC), RG 109 (Canadian Wildlife Service), Vol. 475, File W1.U. 341. Peter Bird, “On the Problem of Radioactive Fallout Levels in Canada's North,” February 1963.
} 
The RPD's “Special Northern Study" (Bird 1964a) was bound up with official efforts to determine if the global dispersal of radioactive fallout had transformed northern Canada into a "nuclear" space. Throughout the circumpolar north, scientists had detected heightened levels of radioactive material in northern food chains. However, I suggest, following historian Gabrielle Hecht's (2012) assessment of the global uranium trade, that the presence of radionuclides in the flesh and bones of caribou did not mean that northern Canada would be treated as a nuclear space. Through its attempt to monitor environmental radioactivity and radioactive exposures in the region, the RPD became an active participant in the negotiation of northern "nuclearity" (Hecht 2012). Hecht defines nuclearity as the way in which specific nations, places, programs, or technologies are designated as nuclear or nonnuclear and argues that its spatial and temporal parameters are unevenly distributed and inherently unstable (2012, pp. 14-15). Rather than a fixed ontological category with rigid boundaries, nuclearity, Hecht argues, is a "technopolitical phenomenon that emerges from political and cultural configurations of technical and scientific things, from the social relations where knowledge is produced" (2012, p. 15). Indeed, the RPD's status as an arbiter of northern nuclearity was tied to its ability to develop the technological capacity and scientific methods required to detect, measure, and monitor radioactive exposures across the vast geographical expanse of northern Canada.

The official narrative of the northern monitoring program is indicative of the increasing belief that postwar Canadian governments held in the ability of scientific institutions to render northern environments legible through conceptual frameworks, scientific methods, and technologies developed elsewhere (Bocking 2013; Power and Keeling 2018; Coates 1994). As the northern monitoring program expanded, the RPD increasingly linked its "epistemic authority" (Gieryn 1999, p. 1) to a particular combination of scientific practice and technological development. ${ }^{2}$ However, a reading of the archival records produced by scientists and officials involved in the northern monitoring program reveals the instability of the RPD's technoscientific framing of northern environmental radioactivity. ${ }^{3}$ As a southern research and public

\footnotetext{
2 Sociologist of science Thomas Gieryn argues that epistemic authority refers to the "legitimate power to define, describe, and explain bounded domains of reality" (1999, p. 1). See Bocking (2009) for a specific examination of northern science.

${ }^{3}$ My analysis of the northern monitoring program is based primarily on an examination of two archival collections that were produced through the RPD's interactions with officials, scientists, and field agents in the Canadian Wildlife Service (CWS) and the Department of Indian Affairs and Northern Development (DIAND). Library Archives Canada (LAC), RG 85 (Northern Affairs Program), Vol. 2081, File 1003-3-14 (1): Sub-Committee on Anthrax and Radiation; and LAC, RG 109 (Canadian Wildlife Service). Vol. 475 File W1.U 341: Radioactive Contamination. These documents cover the operations of RPD officials and scientists until 1967. This was a critical period in the RPD's northern monitoring program, which included the completion of the first major survey of exposures. The RPD's operational records, which are housed in Canada's federal archives, cover the entirety of the temporal period during which the northern monitoring program was in operation, including the results of the 1967-1969 survey discussed below (see LAC, RG 29, Operational Records of the Radiation Protection Bureau, 1950-1984; RG 29, Files of the Radiation and Protection Branch, 1959-1979). Although I have submitted formal requests to access these records through the federal Access to Information Act, closures and delays in processing due to Covid-19 will prevent me from accessing these materials before publication of this paper. In the absence of these documents, I draw on published scientific papers and government reports to piece together the final years of the RPD's Special Northern Study. For a relevant discussion of the
} 
health institution based in Ottawa, the RPD relied on existing and emerging colonial infrastructures (Cowen 2020) to overcome the geographical challenges associated with monitoring radioactive exposures in northern Canada. Throughout the duration of the northern monitoring program, the RPD established institutional linkages with agencies in Canada's northern administration and sought to enroll northern residents, researchers, and wildlife managers as participants in the northern investigation. Connections forged through the establishment of this network were vital to the RPD's northern monitoring program's legitimacy. ${ }^{4}$

In Canada, government agencies, federal scientists, and public health officials emphasized the logic of the threshold as they sought to determine whether northern Canada had been transformed into a nuclear space. By asserting that exposure levels had already exceeded the "safe limits," Pruitt (1962) implied that northern Canada had been rendered nuclear by the particular way in which radionuclides moved through Arctic ecosystems. As officials in Canada moved to test Pruitt's claims, they based their assessment of northern radioactive exposures on threshold values established by international scientific committees and radiological health organizations (ICRP 1959a, b; Federal Radiation Council 1960). Intended to delineate a boundary between ostensibly safe and unsafe levels of radioactive exposure, the threshold, I suggest, represented a technopolitical apparatus (Burch 2019; Hecht 2009) that was developed in distant institutional contexts and used by RPD officials to interpret and frame dynamic socioecological relationships in northern Canada. For Canada's public health officials, the question of whether or not exposure levels had exceeded the "safe limits" —or threshold values — was fundamental to determining whether radioactive fallout had transformed northern Canada into a nuclear space. However, rather than a natural or stable boundary, the concept of a threshold for radiological hazards proved to be a site of contested knowledge claims, persistent debate, and scientific uncertainty (Hamblin 2008; Cram 2016; Walker 2000).

This essay is a historical-geographical account of the way in which scientists and public health officials conceptualized and assessed northern radioactive exposures in the late 1950s and 1960s. Drawing on Hecht's description of nuclearity's historical and geographical contingencies, the paper attends to the spaces in which scientists and public health officials negotiated the placement of the boundary between the nuclear and nonnuclear in northern Canada. Over the past two decades, historical geographers of science have paid increasing attention to the "situated nature of scientific knowledge production and reception and the migratory patterns of science on the move" (Finnegan 2008). Stephen Bocking argues that historical geographies

\footnotetext{
Footnote 3 (continued)

archival inclusions and exclusions engendered by the high degree of state involvement in nuclear projects, see Pitkanen and Farish 2018, p. 874.

${ }^{4}$ Researchers and officials involved in the northern fallout studies used the terms Eskimo to refer to Inuit, Iñupiat, Inuvialuit, and Yupik communities, and Indian to refer to First Nations. I have attempted to use specific and currently accepted terminology in cases where I am able to identify an individual's community or nation. When quoting officials and reports, however, I have maintained the language used in the reports if it reveals the racial and colonial aspects of the monitoring programs. For more on terminology and naming Indigenous communities and nations, see Kaplan (n.d.).
} 
of science have demonstrated the importance of place and movement to the production of scientific knowledge about northern contaminants; "like contaminants themselves," Bocking writes, "knowledge about them is located in specific places, and can move" (2017, p. 425). Like the global dispersal of nuclear fallout, northern nuclearity was not bound by political borders. Indeed, an examination of the RPD's assessment of northern radioactive exposures highlights the limits of national approaches to nuclear histories (Abraham 2006). By following the movement of ideas about radioactive contamination in northern environments through an emergent transboundary scientific network, this paper examines the relationship between the spatiality of environmental radioactivity and the production of scientific knowledge about radioactive exposures in northern Canada.

In the first section, I outline how the global dispersal of nuclear fallout produced by atmospheric nuclear tests became a problem for Canadian public health officials in the mid-1950s. In this section, I demonstrate that increasing awareness of the fallout problem reshaped official understandings of radiation exposures and, ultimately, led to the emergence of the RPD as a critical institution in the state's public health approach to radiation protection. The historical analysis then turns to northern Alaska, where a group of scientists involved in a series of bioenvironmental studies funded by the US Atomic Energy Commission (AEC) contributed to the documentation of the ecological mechanisms underpinning a distinct northern pathway of exposure. Due to the particular way that radioactive material moved through the lichen-caribou-human food chain, biologists and ecologists throughout the circumpolar north believed that northern animals and people were at risk of heightened radioactive exposures. The dissemination of AEC-funded research through unofficial channels heightened concerns about radioactive exposures in northern Canada. The third section examines the RPD's attempt to assess the severity of radioactive exposures in northern Canada by developing a technoscientific monitoring program. In this section, I consider the scientific methods employed by RPD scientists and officials as they monitored radioactive exposure levels in communities across northern Canada. In the conclusion, I reflect on the way in which the RPD's monitoring program was linked to the establishment of the boundary between the nuclear and nonnuclear in northern Canada.

\section{Monitoring Fallout}

In 1945, radioactive contamination was transformed into a global environmental problem. Since the mid-1920s, scientists had been aware of the somatic and genetic hazards posed by exposure to X-rays and radium (Boudia 2007). However, the 1945 detonation of the first atomic weapon at the Trinity test site in New Mexico, and the US bombing of Hiroshima and Nagasaki, transformed anthropogenic radioactive contamination into a planetary force (Martin and Harbinson 1979; Masco 2015). These first nuclear explosions released vast amounts of radioactive debris into the atmosphere, which was deposited as fallout across the earth's surface over a period of several months (UNSCEAR 1958, p. 11). The subsequent development of national atmospheric nuclear testing programs radically altered the scale of the 
"fallout problem" (Commoner 1958). Between 1953 and 1958, the US, UK, and the Soviet Union conducted more than 220 atmospheric nuclear tests, which caused widespread concern about radioactive contamination and exposures (Higuchi 2018; Pavlovski 1998, p. 219; Pochin 1983, p. 75).

As scientists and public health officials assessed radioactive exposures, they had to negotiate the unstable terrain of threshold values. In the postwar period, governments in North America adopted with only minor modifications the International Commission on Radiological Protection's (ICRP) recommendations on safe levels of exposure to radioactive material (Bird 1964a; Hamblin 2008, p. 5; Stephens 2002, p. 96; Martin and Harbinson 1979, p. 59). However, the concept of a safe level of exposure changed over time. During the 1950s, biologists and geneticists increasingly questioned the existence of a threshold dose for certain forms of biological damage (Martin and Harbinson 1979, p. 59; Hamblin 2008, pp. 11-15; Cram 2016, pp. 522-524). As scientists produced new knowledge about radioactive exposures, the ICRP replaced the term tolerance dose, which implied a level of exposure below which somatic damage would not occur, with the concept of a maximum permissible dose (Martin and Harbinson 1979, p. 59), which was defined as the level of exposure that carried "a negligible probability of severe somatic or genetic injuries" (ICRP 1959a, p. 9). According to the ICRP, the effects that would likely be caused by a permissible dose "are limited to those of a minor nature that would not be considered unacceptable by the exposed individual and by competent medical authorities." Severe somatic injuries, such as leukemia, the ICRP stated, "would be limited to an exceedingly small fraction of the exposed group; effects such as shortening the life span, which might be expected to occur more frequently, would be very slight and would likely be hidden by normal biological variations" (1959a, p. 9).

The establishment of threshold values was not a politically neutral project. The ICRP and the governments that adopted its recommendations viewed a permissible dose as one that would "produce effects that could be detectable only by statistical methods applied to large groups" (ICRP 1959a, p. 9). However, as sociologist of science Soraya Boudia argues, international regulatory frameworks, such as the ICRP's recommendations, served to increase the social acceptability of controversial nuclear technologies by promoting the idea that governments and the nuclear industry were managing and regulating the attendant radiological risks and hazards (Boudia 2007, p. 402; see also Higuchi 2018, p. 102). Ultimately, the adoption of the "maximum permissible dose" concept indicated a broader shift in the practice of radiation protection, in which governments decided that a certain level of human radiation exposure was both inevitable and acceptable (Cram 2016, p. 522).

In the late 1950s, amid the political and scientific debate about radioactive fallout's environmental and health effects, nuclear powers began negotiations to curb or end atmospheric test programs (Higuchi 2018). A voluntary moratorium on atmospheric nuclear detonations, initiated in 1958, resulted in a dramatic reduction in short-lived fission materials in the atmosphere and lower elevations (Higuchi 2018; Wilson 1967, p. 4). However, the moratorium, which ended in 1961, was also shortlived. In the three months following the resumption of tests, the Soviet Union conducted more than 50 nuclear detonations over the Arctic (Wilson 1967, p. 4). In 1963, the US, UK, and Soviet Union signed the Limited Test Ban Treaty (LTBT), 
which placed a moratorium on nuclear detonations in the atmosphere, ocean, and outer space and restricted signatories to underground nuclear tests (US Department of State 1963; Masco 2015, p. 143). By the time the LTBT came into effect, however, radioactive fallout represented a "planetary industrial signature" that was inscribed at multiple scales and different levels into every being living on Earth (Masco 2015, p. 151).

The global dispersal of radioactive fallout precipitated a series of transformations in the Canadian government's approach to radiation protection. In 1949, the federal government assigned the Department of National Health and Welfare (DNHW) to manage radiation protection programs in the country. As J.W. Monteith, Minister of DNHW, explained, the department's initial responsibility involved "advising the Atomic Energy Control Board on the health aspects of the use of atomic energy and its by-products" (Monteith 1959, p. 356). Due to the complexity of monitoring and maintaining the health of "radioisotope workers," the DNHW established the Radiation Protection Division (RPD), a separate unit within the department that employed "highly trained" medical professionals and public health officials with expertise in the radiological sciences (Monteith 1959; DNHW 1955, p. 56). Initially, the RPD focused on occupational radiation hazards and had three related functions: in addition to advising the Atomic Energy Control Board, the RPD undertook physical measurements of radiation exposures and conducted clinical studies of the somatic and genetic effects of radiation on humans (Monteith 1959, pp. 356-359).

By the mid-1950s, however, Canadian public health officials were growing increasingly aware of radiation hazards outside of occupational settings. In particular, the initiation of nuclear testing programs led officials in the RPD to conclude that the "widespread distribution of radioactive fallout ... would result in some degree of radiation exposure for members of the general public" (Bird 1964a, p. 1029). As the scale of nuclear testing increased, so too did concern about environmental radioactivity (Bird 1964c, p. 1115). Following developments in the international public health and radiation protection communities, the RPD expanded its investigations beyond occupational settings and focused more broadly on radiation sources that contributed to the general population's exposure levels. This shift in priorities was supported by changes in the division's allocation of funds and resources. By the beginning of the 1960s, approximately fifty percent of the RPD's resources were devoted to the "assessment of the radiation exposure of members of the public from radioactive fallout, effluents from nuclear reactors, natural background radiations and x-rays used for medical purposes" (Bird 1964c, p. 1115).

To address concerns about radioactive fallout in Canada, the RPD initiated a "special study" in 1955 (DNHW 1955, p. 127). Over the next eight years, the RPD's investigation grew into a nationwide fallout monitoring program. Although the program was administered and coordinated by the RPD, it depended to a large extent on the support and infrastructural capacities of the Department of Agriculture, the Meteorological Services Branch of the Department of Transport, and the participation of pathologists at multiple hospitals throughout the country. As Peter Bird, Chief of the RPD, explained, "[b]ecause of the large number of factors that affect the distribution and deposition of radioactive fallout and its subsequent passage through the food-chain and into man, the program is made up of several separate but 
interrelated studies" (1964c, p. 1115). By 1963, the RPD collected milk, wheat, soil, precipitation, and air samples from 96 locations across the country. In support of the RPD's efforts, pathologists at multiple Canadian hospitals provided the division with human bone samples for testing and analysis (1964c, p. 1115).

While the RPD drew on interdepartmental linkages to compile a body of scientific evidence from across the country, officials aimed to develop the infrastructural capacity required to administer the fallout monitoring program from the division's headquarters in Canada's National Capital Region. In 1964, the RPD opened its new headquarters in Ottawa, which housed the division's laboratories where scientists tested and analyzed samples received from sites across the country (DNHW 1966a, b, p. 81; Bird 1964c). A significant development in the early 1960s was the RPD's construction of a whole-body counting system located at its headquarters. The system, which used "large scintillation detectors in a heavily shielded enclosure," was developed to measure the radioactivity content of living individuals (Bird 1964c, p. 1115). The tests and measurements made at the RPD's laboratories in Ottawa were a critical aspect of the division's attempt to determine the geographical distribution of fallout in Canada. Through these developments, and with the support of Canada's federal bureaucracy, the RPD became firmly entrenched as a critical institution in the government's attempt to monitor and manage radioactive exposures resulting from the dispersal of fallout throughout Canada. ${ }^{5}$

Although nuclear fallout had transformed radioactive contamination into a global environmental problem, scientific investigations demonstrated that its impacts were not distributed evenly across the earth's surface. Like Canada, other state-based scientific institutions established monitoring programs in the late 1950s and early 1960s to investigate the spatial and temporal dimensions of fallout dispersal. In a review of fallout data produced by global monitoring programs, climatologist Cynthia Wilson (1967, pp. 1-4) noted that the highest concentrations of radioactive fallout at the earth's surface were located at sites between $40^{\circ}$ and $60^{\circ}$ North, slightly to the south of the Arctic. However, despite the detection of relatively lower levels of fallout throughout the circumpolar north, many scientists believed that there were still considerable radiological hazards associated with the accumulation of radioactive material in Arctic environments. Indeed, as scientific investigations demonstrated, the risk of radioactive exposure was not determined solely by the amount of radioactive material in the environment. Instead, the environmental effects and health consequences of radioactive fallout were shaped profoundly by local ecological conditions (Bocking 2017, p. 428).

\footnotetext{
${ }^{5}$ From 1963 to 1968, the Department of National Health and Welfare released reports containing data and findings from its ongoing investigations in Data from Radiation Protection Programs, a periodical published in English and French.
} 


\section{Mapping a Northern Pathway of Exposure}

Before the signing of the LTBT, several scientists and members of northern Indigenous communities began to voice their concern about radioactive contamination in Arctic environments (Kirsch 2005, pp. 86-88). Their worries were exacerbated by the amount of radioactive debris released by Soviet tests above the Arctic and the accretion of scientific evidence regarding the existence of a distinct northern pathway of exposure for radionuclides. One of the first indications that northern environments were vulnerable to radioactive material bioaccumulation came from northern Scandinavia where scientists determined that reindeer had considerably higher exposure levels than other grazing animals, including groups of animals located closer to nuclear test sites (Bocking 2017; Liden 1961). ${ }^{6}$ Further, in 1959, Canadian botanist Eville Gorham documented the capacity of lichens to accumulate higher concentrations of radioactive contamination than flowering plants (Gorham 1959; Bocking 2017, pp. 428-429). Although Gorham was unable to explain the ecological mechanisms underlying this phenomenon, his research did suggest broader implications for people and animals throughout the circumpolar north: "The chief practical conclusion to be drawn from this work," Gorham stated, "is that animals feeding on mosses and lichens may well exhibit high intakes of radioactive fall-out" (1959, p. 329).

Following the publication of Gorham's findings, the US Atomic Energy Commission (AEC) played a vital role in the development of an ecological understanding of the relationship between northern environmental radioactivity and radioactive exposures. In 1957, the AEC established Project Plowshare, a research and development program that was intended to use nuclear weapons for "geographical engineering" (Masco 2015; Kirsch 2005). The following year, the AEC selected Cape Thompson in northwestern Alaska as the future site of Project Chariot, which involved the planned nuclear excavation of an experimental harbor north of the Bering Strait (Cittadino 2018; O’Neill 2007; Kirsch 2005; Coates 1989). Partly in response to political opposition and scientific concern about Project Chariot's potential environmental impacts, the AEC funded a series of bioenvironmental studies for the region (Millar and Mitchell 1998). John Kelly, director of Project Plowshare, later wrote that the bioenvironmental studies were intended to develop an understanding of Arctic ecological systems so that the AEC could estimate the "biological cost" of the excavation, establish environmental baselines that could be used in post-detonation research, and "determine radiation levels and the distribution of radioisotopes in the biota and physical environment in pre- and post detonation time" (Wilimovsky and Wolfe 1966, p. iv). The planned nuclear excavation, however, did not take place. In 1962, the Project Chariot proposal, which had been met with staunch opposition from Alaskan Iñupiat communities and American environmental organizations, was withdrawn by the AEC.

\footnotetext{
${ }^{6}$ Scientists classify caribou and reindeer as subspecies of species Rangifer tarandus. While caribou evolved in North America, reindeer evolved in northern Europe. AWF Banfield, A Revision of the Reindeer and Caribou Genus Rangifer (Ottawa: Queen's Printer, 1961).
} 
Although Project Chariot was canceled, the research funded through the bioenvironmental program transformed scientific understandings of northern environmental radioactivity. An essential aspect of the bioenvironmental program was the production of baseline data concerning environmental radioactivity in the Cape Thompson region (Kirsch 2005, p. 95). By analyzing the stomach contents and droppings of animal species located in the region, investigators produced visual representations of northern food webs, which they used to model the flow of energy through local ecosystems (Kirsch 2005, p. 95). Further, a group of scientists affiliated with the University of Alaska-Fairbanks (UAF) claimed to have verified Gorham's findings by demonstrating that lichens found in the study area had significantly higher levels of strontium-90 than other Arctic plants (Alaska Conservation Society 1961, p. 23). Several investigations involved the intentional release of radioactive material into the northern environment (ACHRE 1995, chap. 11). In these studies, scientists placed "mixed fission material" into bounded sample plots and small pits, and monitored the movement of radioactive material to determine transportation and absorption rates (ACHRE 1995, chap. 11). An investigation led by Wayne Hanson, a biologist working for the AEC at the Battelle Memorial Institute in Washington State, established a direct correlation between caribou consumption and heightened Cesium-137 exposure levels (Hanson et al. 1966). These studies represented a critical step in the development of an ecological understanding of the lichen-caribouhuman pathway of exposure.

During the early years of the Cold War, the relationship between the AEC and the ecological sciences proved to be a "double-edged sword" (Hagen 1992, p. 100). While the AEC provided ecologists with critical sources of funding and new research tools and opportunities, it also created many of the environmental problems that ecologists were investigating (Kirsch 2005, p. 57; see also Hagen 1992; Bocking 1995; Martin 2018). The tensions engendered by the multiple and competing interests at play in this relationship shaped the content and conduct of the AEC's bioenvironmental studies. One particularly salient controversy involved William Pruitt, who had been hired by the Department of Biology at UAF to conduct a study of terrestrial mammals for the bioenvironmental program. During his research, Pruitt became increasingly interested in understanding the ecological mechanisms underlying the bioaccumulation of radioactive material in caribou bodies. The AEC, however, reduced funding for the costly caribou studies and rejected Pruitt's proposal to study the relationship between caribou and Arctic vegetation (Millar and Mitchell 1998, pp. 293-294).

Concerned about AEC censorship, Pruitt and his colleagues developed a strategy that involved disseminating their concerns and research findings outside of officially approved channels (Millar and Mitchell 1998, p. 294; Kirsch 2005, p. 98). The fallout from their decision to publicly oppose Project Chariot was immediate and severe. Pruitt's involvement in this public controversy "earned him the enmity" of both AEC officials and UAF administration, and, ultimately, led to the termination 
of his position in the Department of Biology (Millar and Mitchell 1998, p. 295). ${ }^{7}$ Despite significant personal and professional consequences, the strategy adopted by the dissenting UAF scientists was, in many ways, a "contested success" (Millar and Mitchell 1998). As geographer Scott Kirsch argues, Pruitt and his colleagues effectively challenged the authority of the AEC's claims over the Cape Thompson region's environmental future by shifting the boundaries of dissent and enrolling new actors and groups in the local opposition movement (Kirsch 2005, pp. 78, 98).

In the early 1960s, UAF scientists established a transboundary network of communication that involved experts, activists, and government agencies that extended beyond the US and included officials in the Canadian government. In publications and correspondence with members of this emergent network, the dissenting scientists suggested that the threat of heightened radioactive exposure levels in the North was not merely a hypothetical future scenario that depended on project Chariot proposal's success. Drawing on research from Alaska and Scandinavia, they insisted that current levels of environmental radioactivity represented a profound threat to people living in northern communities due to the movement of radionuclides through the lichen-caribou-human food chain (see Alaska Conservation Society 1961).

By disseminating their findings through unsanctioned channels, Pruitt and his former colleagues at UAF contributed to the development of terms by which the northern environment—including northern Canada—could be understood as a nuclear space. In 1962, Les Viereck, a former employee of UAF and participant in the AEC's bioenvironmental research program, provided officials in the Canadian Wildlife Service (CWS) with a "restricted" report on movement of radioactive materials through the lichen-caribou-human food chain in northern Alaska. Following this document's receipt, E.H. McEwan, a mammologist with the CWS, prepared a report on the dangers of northern environmental radioactivity. McEwan's report was subsequently tabled and discussed at a meeting of the Administrative Committee for Caribou Preservation. This joint federal-provincial body developed policy recommendations for senior levels of government. ${ }^{8}$ Following this meeting, officials with the CWS prepared and submitted a memorandum to the Department of Northern Affairs and National Resources (DNANR), which outlined the confidential report's findings and commented on its implications for northern Canada. Acknowledging the "distinct probability of transmission" of Strontium-90 and Cesium-137 to humans "through the food chain mechanism," the CWS recommended the immediate establishment of an "intensive" program of research. ${ }^{9}$

However, it was William Pruitt's 1962 essay on radioactive fallout and caribou that garnered the most interest among Canadian wildlife managers, public health

\footnotetext{
7 A full consideration of the scientific controversies engendered by the AEC's involvement in the bioenvironmental studies is beyond the scope of this essay. For more on this important episode in northern nuclear history, see Millar and Mitchell (1998); Kirsch (2005); O’Neill ([1994] 2007).

8 This restricted report is now open for public access in Canada's federal archives. See LAC, RG 109, Vol 475, File Wl.U. 341. For more on the caribou committee, see Sandlos (2007, p. 206).

9 LAC, RG 109, Vol 475, File W1.U. 341, 20 December 1962, "Memorandum for the Deputy Minister."
} 
officials, and members of the country's northern administration. ${ }^{10}$ Shortly after his contract at UAF was terminated, Pruitt published an article in The Beaver, a Canadian historical magazine, in which he articulated the ecological mechanisms underlying the lichen-caribou-human pathway of exposure. Drawing on emergent understandings of Arctic ecology and research from northern Alaska, Pruitt emphasized the important role that lichen played in facilitating the movement of radioactive material through the northern environment. This slow growing plant, he explained, was a combination of an alga and a fungus that had evolved extremely efficient mechanisms for acquiring nutrients from air-borne particles. Pruitt noted that lichen, which were common throughout Arctic tundra ecosystems, were capable of retaining "virtually $100 \%$ of the radioactive particles which fall onto them" (1962, p. 25). Due to its "peculiar physiology," the lichens upon which migratory caribou grazed tended to be highly contaminated with fallout from atmospheric nuclear tests. The implications for people in northern Canada, Alaska, and Scandinavia, Pruitt suggested, were clear: "Since the caribou is the base of the food chain in the North, turning vegetation into a form that other animals, including man, can utilize," he wrote, "one would expect the entire food chain to be contaminated" (1962, p. 25).

Pruitt's article heightened concerns about environmental radioactivity in northern Canada. It also exposed a considerable lacuna in scientific and public health understandings of radioactive exposures throughout the country. In December 1962, E.A. Côté, the Deputy Minister of DNANR, sent a memorandum to the CWS requesting information about the relationship between nuclear fallout and caribou. In the memo, Côté noted that he had recently read Pruitt's article in The Beaver and expressed some concern about the biologist's hypotheses regarding radioactive exposures in northern Canada. ${ }^{11}$ Although CWS officials stated that there was "no factual basis" to support Pruitt's assertions, their response revealed that the federal government had not yet undertaken a systematic investigation of radioactive exposures in the North. However, CWS officials noted that they were aware of the situation and were in the process of preparing a joint investigation with the DNHW that would focus on radioactive exposures in locations where Indigenous peoples consumed caribou meat. ${ }^{12}$ In his response, Côté asserted that the investigation should not be limited to the CWS and the DNHW due to the connection between caribou and northern Indigenous peoples' health. ${ }^{13}$ Côté immediately sought to establish connections between the CWS and members of the Northern Administration Branch to ensure that the appropriate agencies could proceed with the necessary studies as quickly and efficiently as possible. In closing, he stated: "I think this matter should not be looked at in the narrow context of wildlife. In view of the potential explosiveness of a nuclear

\footnotetext{
10 In 1963, Peter Bird, Chief of the Radiation Protection Division, claimed that much of the "recent interest" in fallout and caribou was related to Pruitt's article in The Beaver. See LAC, RG 109, Vol 475, File W1.U. 341, February 1963, "On the Problem of Radioactive Fallout Levels in Canada's North."

11 LAC, RG 109, Vol 475, File Wl.U. 341, 28 December 1962, "Memorandum for Parks Branch."

12 LAC, RG 109, Vol 475, File Wl.U. 341, 16 January 1963, "Memorandum for Mr. E.A. Côté."

13 LAC, RG 109, Vol 475, File Wl.U. 341, 22 January 1963, "Memorandum for National Parks Branch."
} 
debate in the House of Commons, I think this matter should be considered in the light of all factors."14

\section{Body Burden: Mapping the Uneven Geographies of Northern Exposures}

By early 1963, negotiations were underway to establish the terms and administrative parameters of a joint investigation of radioactive exposures in northern Canada. As Peter Bird, Chief of the RPD, explained, the "special features" of the northern food chain, particularly the lichen-caribou-human pathway of exposure, made it "desirable" to investigate radioactive exposures in the North through a separate program (Bird 1964c, p. 1116). From its inception, officials agreed that the investigation's scale, and the complications associated with conducting scientific research in northern Canada, necessitated a cooperative agreement that involved multiple government agencies. As the project's parameters took shape, members of Northern Health Services, RPD, DNHW, Northern Administration Branch, and the Northern Co-ordination and Research Center of the DNANR became key participants in the investigation. ${ }^{15}$ Due to the RPD's position within the federal government's public health approach to radiation protection and its development of specific nuclear technological capacities, the division was well positioned to lead the "Special Northern Study." 16 By the end of the year, the RPD had assumed responsibility for coordinating the activities of the program's multiple participating agencies, and determining whether radioactive exposure levels in northern Canada had indeed exceeded the "safe limits."

For the RPD, radioactive exposures in northern Canada represented a geographical problem that was complicated by the multiscalar dimensions of environmental radioactivity. Global monitoring programs had demonstrated that radioactive fallout was distributed unevenly across the earth's surface, and scientific investigations had revealed how local ecological conditions - such as vegetation diversity, precipitation rates, and the presence of grazing animals - regulated the movement of radionuclides through northern food webs. Based on a review of literature from Alaska and Scandinavia, Canadian officials determined that Cesium-137 and Strontium-90 represented the most significant fallout radionuclides present in the northern environment. ${ }^{17}$ With half-lives of approximately thirty years, these two radionuclides posed long-term radiological hazards for caribou herds and human communities throughout the region (Hanson 1966). However, each posed different radiological risks and uncertainties due to the particular ways that they accumulated in caribou

\footnotetext{
14 LAC, RG 109, Vol 475, File W1.U. 341, 22 January 1963, "Memorandum for National Parks Branch."

15 LAC, RG 109, Vol 475, File W1.U. 341, N.D., "Draft Letter," Peter Bird to Regional Superintendents of National Health Services.

16 LAC, RG 109, Vol 475, File W1.U. 341, 20 December 1962, "Memorandum for the Deputy Minister".

17 LAC, RG 109, Vol 475, File W1.U. 341, February 1963, Peter Bird, "On the Problem of Radioactive Fallout Levels in Canada's North."
} 
bodies (Palmer et al. 1963; Hanson 1965a, b; Pochin 1983). Whereas Strontium-90 concentrated in caribou bones, Cesium-137 accumulated in the animal's flesh and muscle. Because it accumulated in the parts of caribou bodies consumed most commonly by people, RPD officials expected to find "that the ratio of caesium-137 in eskimos and indians (sic) to 'southern' Canadians will be higher than the same ratio for strontium-90." ${ }^{\prime 18}$ At this early stage in the research program, however, there was considerable uncertainty about the biophysical determinants of human exposure levels: it was entirely possible, Bird wrote, that the ingestion of Cesium-137 through the consumption of caribou meat was being offset by the "rapid elimination" of the radionuclide from the body. ${ }^{19}$

A critical step in assessing the spatial distribution of risk was determining if there was a relationship between nuclear fallout and the accumulation of radionuclides in caribou bodies. Although the RPD operated a nationwide fallout monitoring program, which included data from six locations in northern Canada, the "[e]mphasis on the food chain-human side of the program," Bird noted, "has been directed to the more heavily populated areas of Canada." ${ }^{20}$ Before the establishment of a formal agreement among the participating agencies, the RPD initiated a "preliminary investigation" of Strontium-90 in caribou bones. In the early 1960s, the CWS, recognizing that there may be a future need to study the relationship between fallout and caribou, had built up an inventory of caribou bones, which it made available to the RPD for the Strontium-90 assay. In a report shared with participating agencies, Peter Bird explained that caribou bone samples selected from locations across northern Canada would be tested for radioactive content. The results would be compared with the RPD's soil data to determine if "differences in caribou bone levels can be associated with the differences in a deposition" of radioactive fallout. ${ }^{21}$ The decision to begin with a preliminary investigation of Strontium-90 was also indicative of the RPD's inchoate monitoring and infrastructural capacity. At the beginning of 1963, the RPD's whole-body counter, which was designed to detect Cesium-137 concentrations in humans, was still under construction at its new headquarters in Ottawa. Bird stated that if the results of the Strontium- 90 tests revealed the need for further investigation, the RPD would use the whole-body counter to conduct Cesium-137 body burden measurements following its completion. ${ }^{22}$

By the beginning of 1964, the federal bureaucracy had finalized the administrative details for the Special Northern Study, and the RPD was in the process of

\footnotetext{
${ }^{18}$ LAC, RG 109, Vol 475, File W1.U. 341, February 1963, Peter Bird, "On the Problem of Radioactive Fallout Levels in Canada's North."

19 LAC, RG 109, Vol 475, File W1.U. 341, February 1963, Peter Bird, "On the Problem of Radioactive Fallout Levels in Canada's North."

20 LAC, RG 109, Vol 475, File W1.U. 341, February 1963, Peter Bird, "On the Problem of Radioactive Fallout Levels in Canada's North."

21 LAC, RG 109, Vol 475, File W1.U. 341, February 1963, Peter Bird, "On the Problem of Radioactive Fallout Levels in Canada's North."

22 LAC, RG 109, Vol 475, File W1.U. 341, February 1963, Peter Bird,"On the Problem of Radioactive Fallout Levels in Canada's North."
} 
coordinating the various components of the research program. ${ }^{23}$ In a draft letter to the Regional Superintendents of the Northern Health Service, Peter Bird provided a detailed overview of the proposed studies, all of which, he argued, "must be undertaken if we are to be able to make an assessment of the fallout problem in Canada's North." 24 The RPD's investigation of radioactive exposures among people and animals in northern Canada comprised five separate though interrelated studies: analysis of Cesium-137 in caribou, reindeer, and moose samples; analysis of urine specimens for Cesium-137 content, with accompanying information on dietary habits; whole-body counting for Cesium-137 in northern residents (measurements to be conducted at RPD headquarters in Ottawa); and a study of northern dietary habits (Bird 1964c, p. 1116). In correspondence with officials in the federal government's northern administration, wildlife managers, and members of the northern health services, Bird delivered guidelines for the collection of biological samples that he expected field agents to follow. Failure to adhere to the guidelines and instructions, Bird explained, would render biological samples useless to the research program's scientists. $^{25}$

Because of the role that caribou were believed to play in the transmission of radionuclides to humans, the RPD based its spatial division of the sampling program on migratory caribou herds' movements in northern Canada. To collect samples and map the geographical distribution of radioactive exposures, the RPD divided the northern research area into five discrete regions. Officials later added a sixth region in the eastern Arctic, centered on Baffin Island (see Fig. 1 ). As Peter Bird explained, each area's boundaries corresponded with the ranges of major barren ground caribou herds, among which there was thought to be little interchange of animals. ${ }^{26}$

The RPD's biogeographical division of the North revealed the confidence that the state placed in the ability of scientific wildlife managers to render northern landscapes legible and accessible through the application of scientific methods and visualization technologies developed elsewhere (Bocking 2009). By the beginning of the 1960s, wildlife biologists, armed with aerial surveillance technologies, had established firm boundaries around the major caribou herds in the North American Arctic. These boundaries were accepted by government agencies and employed within emergent herd-based management for caribou (Banfield 1961; Kelsall 1957, 1968). Indeed, the belief that radioactive exposures could be understood and ultimately controlled by managing the relationship between migratory caribou and Indigenous peoples was informed by a long history of colonial conservation and knowledge production in northern Canada. Since the beginning of the twentieth century, caribou conservation had been linked inextricably with the colonial administration of

\footnotetext{
${ }^{23}$ LAC, RG 109, Vol 475, File W1.U. 341, 10 June 1964, Correspondence: Peter Bird (RPD) to V.F. Valentine (Chief, Northern Co-ordination and Research Centre).

24 LAC, RG 109, Vol 475, File W1.U. 341, 10 September 1963, Draft Letter: Peter Bird to Regional Superintendents, Northern Health Services.

25 LAC, RG 109, Vol 475, File W1.U. 341, 10 September 1963, Draft Letter: Peter Bird to Regional Superintendents, Northern Health Services.

${ }^{26}$ LAC, RG 109, Vol 475, File Wl.U. 341, 10 September 1963, Draft Letter: Peter Bird to Regional Superintendents, Northern Health Services.
} 
the North; through the management of caribou, the state sought to manage northern Indigenous peoples and their relationship with northern environments (Sandlos 2007; Kulchyski and Tester 2007).

Despite the establishment of clearly delineated boundaries and explicit instructions, the rigors of northern field research complicated the task of collecting biological samples from each of the designated areas. From the perspective of southern scientists and bureaucrats, the five original research areas-charted neatly on hand-drawn maps and corresponding with caribou herds' ostensibly tidy movements - seemed to make sense. On the ground, however, the reality was much less orderly. As G.F. Parsons, an official with the Northern Co-ordination Research Centre, reminded RPD officials, each of the five areas represented a vast geographical region that was sparsely populated and mostly inaccessible to state-based researchers and field agents. When officers and game wardens did secure a caribou carcass, they often experienced difficulties following the RPD's instructions for preserving and transporting biological samples. ${ }^{27}$ By the end of 1964, Bird was concerned that inconsistencies in field preservation techniques had rendered many of the biological samples unusable.

To preserve the sampling program's integrity, Bird and his colleagues implemented a series of measures intended to "systematize" biological material collection. According to this new system, caribou meat would have to be dried before being shipped to the RPD laboratories. Bird requested that scientists at the Inuvik Research Laboratory - an important site of scientific knowledge production in northern Canada - develop an effective method of drying caribou meat for transportation and scientific analysis. ${ }^{28}$ By 1965, the RPD had compiled a substantial inventory of caribou samples from sites throughout the North (Mohindra et al. 1966). There was, however, significant geographical disparity among the samples being sent to the RPD's headquarters for testing. More than seventy percent of the 220 samples came from just two designated research areas (Area II and Area IV). Although northern administrators placed pressure on field agents to supply samples from all research areas, the RPD's attempts to address the increasing disparity in samples' geographical distribution were mostly ineffective. ${ }^{29}$

By testing and analyzing the samples received in Ottawa, the RPD documented significant spatial and temporal variances in radioactive exposures among migratory caribou. After exposure levels peaked in 1964, tests indicated that Cesium-137 concentrations in caribou decreased by approximately $20 \%$ - from 18,000 to 14,000 picocuries per pound-over the next 12 months (Mohindra et al. 1966, pp. 3-4). For the sake of comparison, the RPD measured the radioactivity content of poultry

\footnotetext{
${ }^{27}$ LAC, RG 109, Vol 475, File W1.U. 341, 20 November 1964, Correspondence: G.F. Parsons (NCRC) to Peter Bird (RPD).

28 LAC, RG 109, Vol 475, File W1.U. 341, 21 December 1964: Peter Bird, "Memorandum: Meeting with representatives from Dept. Northern Affairs and National Resources re Special Northern Fallout Studies."

29 LAC, RG 109, Vol 475, File Wl.U. 341, Correspondence: G.F. Parsons (NCRC) to Peter Bird (RPD); LAC, RG 109, Vol 475, File W1.U. 341, 30 July 1965, Correspondence: Peter Bird (RPD) to J.S. Tener (CWS).
} 


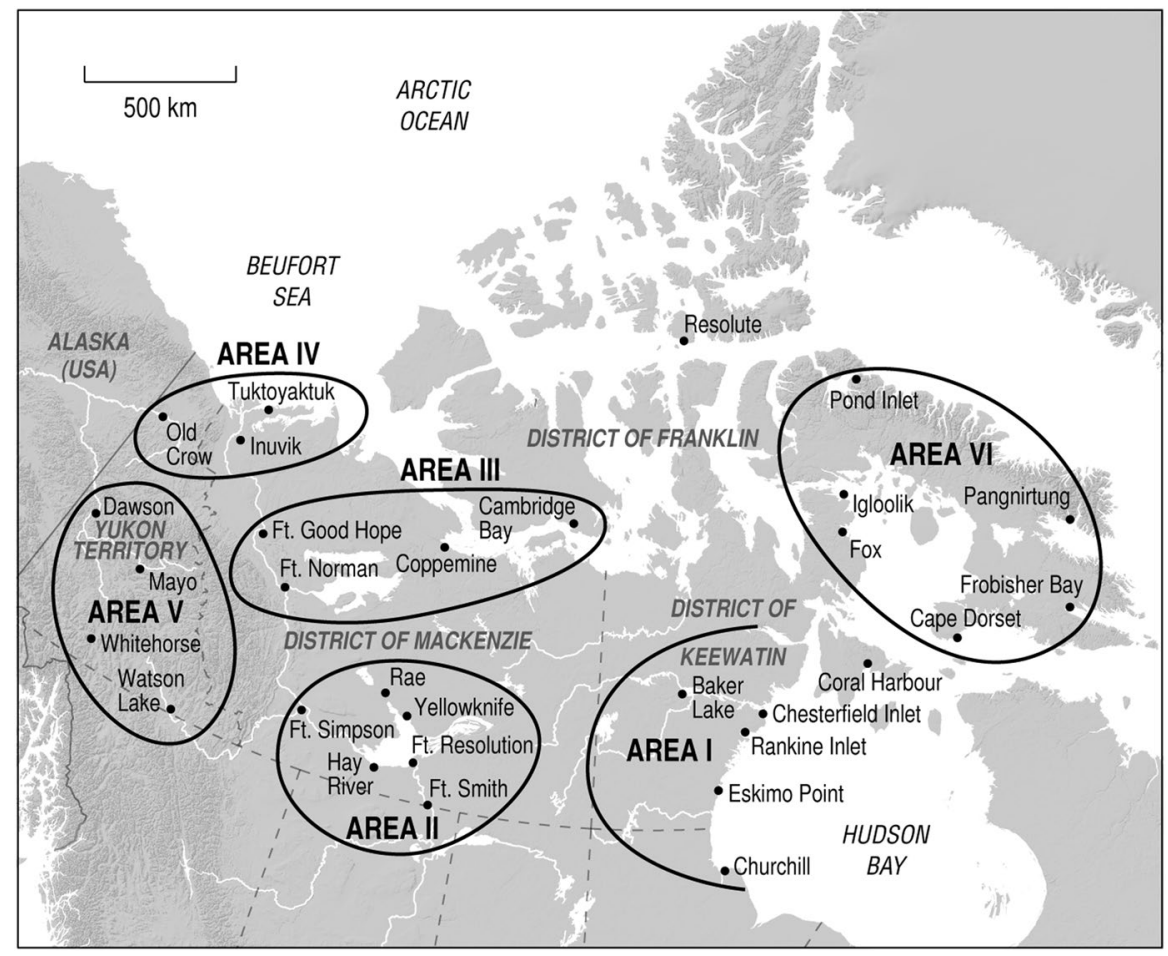

Fig. 1 Map by Eric Leinberger. Originally published in: V.K. Mohindra, Cesium 137 Body Burdens in the Canadian North, Acta Radiologica: Therapy, Physics, Biology 6 (1967): 481-490. See also: LAC, RG 85, Vol. 2018, File 1009-3-13 (1): Sub-Committee on Anthrax and Radiation

samples acquired at a market in Ottawa. For this decidedly southern food source, tests indicated a Cesium-137 concentration of just 24 picocuries per pound of meat (Mohindra et al. 1966, p. 13). Even at 1965 levels, the amount of Cesium-137 detected in caribou meat was more than 580 times greater than that found in Ottawa's poultry sample. Further, the RPD's analysis demonstrated that radioactivity levels among caribou were not uniform across northern Canada. Tests indicated that caribou from Areas I and II (see Fig. 1) had significantly higher body burdens of radioactivity than the herds located within the other four research areas' boundaries. $^{30}$

For the RPD, these tests demonstrated that caribou in northern Canada were still vulnerable to the bioaccumulation of radioactive material, even two years after the LTBT came into force. The question remained, however, whether officials believed that contaminated caribou meat consumption had caused human exposure levels

${ }^{30}$ LAC, RG 85, Vol. 2081, File 1003-3-14 (1), 28 December 1965, Correspondence: G.F. Parsons to Director Northern Administration Branch. 
to exceed the "so-called 'safe limits,", as Pruitt had argued in 1962. To assess the severity of radioactive exposures and the attendant risk to public health, the RPD developed a series of human studies, which involved direct and indirect methods of quantifying Cesium-137 body burdens among northern residents. ${ }^{31}$ Because Cesium-137 accumulated in the parts of caribou bodies most frequently eaten by northerners, RPD officials viewed it as the most significant radionuclide in the northern food web (Bird 1964c; Bird 1968b, p. 631). Although the RPD developed an ancillary study that examined Strontium-90 exposures, the human studies focused primarily on the bioaccumulation of Cesium-137 in human bodies. ${ }^{32}$

By the beginning of 1964, the RPD had established two interrelated human studies through which officials sought to assess the severity and distribution of Cesium-137 body burdens in northern Canada (Bird 1964c). While the first study involved the direct measurement of Cesium-137 body burdens at the RPD's laboratories in Ottawa, the second developed an indirect method of quantifying radioactive exposure levels based on the analysis of urine samples (Bird 1964c, 1968b). Like the caribou studies, however, this approach was challenged by the problem of numbers. Between 1964 and 1967, RPD officials not only struggled to recruit representative numbers of research subjects from the designated research areas, but also had to contend with scientific uncertainty concerning how to quantify body burdens through indirect methods of measurement. ${ }^{33}$ The RPD sought technoscientific fixes to address these issues and continued to draw on official linkages within Canada's northern administration to recruit research subjects.

From the perspective of RPD officials, the whole-body counting system offered the most direct and efficient method of measuring Cesium-137 body burdens (Bird 1968b). In this study, northern residents who had traveled to southern Canada would be recruited by the RPD to undergo testing in the whole-body counting system, which was located at the division's headquarters in Ottawa. In a 1967 presentation at the "Symposium on Circumpolar Health Related Problems," which was held at the University of Alaska, Peter Bird explained how the whole-body counting system operated (Bird 1968b). His discussion emphasized the facility's technical aspects and outlined how its various components operated to ensure the accuracy of recorded measurements (Bird 1968b, pp. 636-637).

However, Bird's presentation also hinted at the limitations of this approach. Because the whole-body counter was located at the RPD's headquarters, he explained, this part of the investigation relied on the "movement of healthy Eskimos into the Ottawa region" (Bird 1968b, p. 637). During the first year of the study, the RPD recruited only 14 Inuit participants from the eastern Arctic to undergo

\footnotetext{
31 LAC, RG 109, Vol 475, File Wl.U. 341, 10 September 1963, Draft Letter: Peter Bird to Regional Superintendents, Northern Health Services.

32 For a discussion of the methods employed to determine Strontium- 90 concentrations in human bones, see Samuels 1967, 1968. For an overview of the collection of human bones, see LAC, RG 109, Vol 475, File W1.U. 341, 10 September 1963, Draft Letter: Peter Bird to Regional Superintendents, Northern Health Services.

33 LAC, RG 85, Vol. 2081, File 1003-3-14 (1), 28 December 1965, Correspondence: G.F. Parsons to Director, Northern Administration Branch.
} 
whole-body counting at the RPD's headquarters in Ottawa. Bird continued to rely on the state's existing colonial administration infrastructures as the RPD sought to increase the number of research subjects. In response to pressure from officials in the DNANR, local administrators across northern Canada agreed to assist in recruiting research subjects by notifying the RPD when Indigenous northerners traveled south to Ottawa. ${ }^{34}$ To "increase and systematize" the flow of subjects for the body burden studies, officials with the Northern Co-ordination and Research Centre agreed to select and make travel arrangements for potential research subjects. ${ }^{35}$ Despite the assistance of local officials, the RPD's efforts were largely ineffective, and the division failed to recruit a representative number of research subjects for its Ottawa-based whole-body counting study.

The RPD also sought a technoscientific fix to the problem of numbers. In an effort to increase the number of people undergoing direct body burden measurements, the RPD initiated the construction of a portable whole-body counter. The Canadian institution based its model on a system created by technicians at the AEC's Hanford Laboratory and adopted by scientists and public health officials investigating radioactive exposures in northern Alaska (Bird 1968b; Hanson 1965). Bird argued that access to this device would facilitate the geographical expansion of the monitoring program and enable the RPD to increase the number of people undergoing direct measurements for Cesium-137 body burdens. Although trials began in 1966, this technology was not fully operational and available for extensive testing until 1967 (Bird 1968b; Tracy et al. 1997).

In the absence of this specialized sensing technology, the RPD relied greatly on an indirect method of quantifying Cesium-137 body burdens, which was based on the analysis of urine samples (Mohindra 1967). Unlike the RPD's massive and immobile whole-body counting system, this method offered a geographically expansive approach to monitoring radioactive exposures across northern Canada. Rather than depending on the recruitment of northern research subjects who had traveled south to Ottawa, the RPD asked participating agencies and health practitioners to collect urine samples from people living in communities across northern Canada. Following collection, the samples were transported to the RPD's headquarters in Ottawa, where they were subject to testing and analysis to determine Cesium-137 levels. Between 1964 and 1967, the RPD conducted tests on 562 urine samples collected from people living in 24 northern communities (Tracy et al. 1997, p. 432). In the RPD's laboratories, scientists and technicians employed gamma spectrometric techniques to measure the Cesium-137 content of the urine samples (Mohindra 1967, p. 484).

The RPD categorizied urine samples according to the consumption of caribou meat, which officials viewed as a primary risk factor for heightened radioactive exposures. Northern health officials were asked to determine and document the

\footnotetext{
${ }^{34}$ LAC, RG 85, Vol. 2081, File 1003-3-14 (1), 4 March 1965, Correspondence: G.F. Parsons to Director, Northern Administration Branch.

35 LAC, RG 85, Vol. 2081, File 1003-3-14 (1), 25 February 1965, Correspondence: G.F. Parsons to Director, Northern Administration Branch.
} 
"dietary habits" of the individuals who provided urine samples for the research program. In its initial proposal, RPD officials established three "classes of diet," which they believed to be characteristic of northern Canada. In an outline of the urine sampling program sent to health officials in northern Canada, Peter Bird provided details on the three dietary classifications. They were: "Native (principally caribou, reindeer, moose, etc.); Native (other foods e.g. fish and sea mammal); 'White' (principally imported store foods)." ${ }^{36}$ As the sampling program progressed, the RPD dispensed with the racial division of dietary classes and instead adopted an alphabetical system of classification. In this organization system, diet class A indicated the consumption of relatively large amounts of caribou and reindeer meat, diet class B represented relatively small amounts of caribou, and diet class $\mathrm{C}$ represented a "northern diet" that did not include caribou or reindeer meat. For comparative purposes, the RPD included diet class D, which represented an "urban diet in Ottawa, Canada" (Mohindra 1967, p. 483).

Although this method facilitated the spatial expansion of the RPD's monitoring program, its effectiveness was compromised by scientific uncertainty regarding the relationship between the urinary content of Cesium-137 and radioactive exposure levels. When the RPD adopted this method, scientists and officials believed they could calculate an individual's radioactive body burden based on the amount of Cesium-137 present in their urine. Underpinning this method of measurement was the assumption that Cesium-137 was excreted in proportion to the amount that was present in the body (Bird 1968b, p. 636). As the study progressed, however, RPD scientists learned that a broad range of poorly understood physiological mechanisms regulated the rate at which individuals metabolized and excreted Cesium-137 (Overton and Quastel 1967; Bird 1968b).

In 1965, the RPD initiated an experimental human radiation study that aimed to clarify the mathematical relationship between urinary Cesium-137 concentrations and radioactive body burdens (Bird 1968b; Overton and Quastel 1967). ${ }^{37}$ Participants in the experimental study voluntarily ate caribou meat that contained "a relatively high concentration" of Cesium-137, and were then monitored to determine the rate at which the radionuclide was excreted in urine (Overton and Quastel 1967, p. 540). The experimental research program was challenged by the RPD's inability to recruit study participants. After two years, only two Indigenous northerners and a small number of other volunteers had participated in the experimental study (Bird 1968b, p. 636; Overton and Quastel 1967). Nonetheless, RPD scientists claimed the experimental findings demonstrated that the relationship between urinary excretion and body burdens was not a simple or linear proportionality. Instead, they stated that as Cesium-137 moved through the human body, kidney functions caused daily variations in excretion levels (Overton and Quastel 1967, p. 540).

\footnotetext{
36 LAC, RG 109, Vol 475, File W1.U. 341, 10 September 1963, Draft Letter: Peter Bird to Regional Superintendents, Northern Health Services.

37 For more on the history of the use of radioactive tracers in health and medical experiments, see Creager (2014); for a specific northern example from Alaska, see Farish (2013).
} 
As officials moved to calculate individual and average body burdens, they cautiously adopted a mathematical formula based on the ICRP's biological data and mathematical models. The formula was based on the assumption that "the amount of cesium 137 in the urine can be taken as a measure of the amount in the body" (Mohindra 1967, p. 486). However, as RPD physicist V.K. Mohindra noted, "precise evaluations cannot be expected" due to the "many factors" that affect the relationship between urinary Cesium-137 concentrations and radioactive body burdens (1967, p. 486).

By 1967, RPD scientists had completed the urine sampling program. Their findings indicated that human exposure levels in northern Canada had peaked in 1965 (Mohindra 1967). Like their counterparts throughout the circumpolar north, Canadian officials observed a correlation between caribou consumption and heightened exposure levels (Mohindra 1967, p. 486). Further, tests indicated that human exposure levels generally followed increases in Cesium-137 concentrations in caribou meat. There was, however, a distinct temporal lag of approximately one year between spikes in caribou and human exposure levels, which scientists attributed to the time that it took for radioactive material to move through the northern food chain (Mohindra et al. 1967). While RPD officials drew a strong connection between caribou consumption and cesium-137 body burdens, they documented geographical variations in radioactive exposure levels. The sampling program's results revealed that body burdens were much higher in the central and eastern Arctic than the western Arctic, where caribou formed an essential part of the local diet. As they had recorded similar levels of fallout at monitoring stations across the region, scientists attributed seasonal and geographic variations in body burdens to fluctuations in the availability of caribou meat and ecological mechanisms they were unable to explain at that time (Mohindra et al. 1967, p. 485).

Did the RPD believe that human exposure levels in communities across northern Canada exceeded the "safe limits," as Pruitt had argued in The Beaver? As RPD scientists and officials analyzed urine samples and calculated radioactive exposure levels, they documented only one case in which an individual's recorded Cesium-137 body burden appeared to exceed the threshold values established by the ICRP (Mohindra 1967, p. 488). Based on an observed urinary Cesium-137 concentration of 19,500 picocuries per liter, the RPD estimated that this individual's body burden was 3.2 microcuries (Mohindra 1967, p. 489). This level of exposure, stated V.K. Mohindra, was only "slightly higher" than the IRCP's maximum permissible dose of 3.0 microcuries for any individual member of the population (1967, p. 489). As RPD scientists outlined the results of the urine sampling program, they emphasized that this case represented an outlier: "It is evident," wrote Mohindra, "that the body burdens of the northern residents referred to in this study are generally well below the acceptable level" (1967, p. 489). Based on an examination of the aggregated results, which were classified according to the established dietary classes, the RPD suggested that caribou eaters "can be much more significantly exposed than the average for the rest of the population" (Bird 1968b, p. 638). Nevertheless, officials were confident in their determination that, on average, northern body burdens "correspond to radiation doses well within the dose limit" recommended by the ICRP (Bird 1968b, p. 638). Although Bird (1968b) emphasized the need for further studies, by 1967, 
RPD officials had concluded, "[t]here will be no expectation of a significant effect on the health of the population and no necessity to consider restricting the normal consumption of caribou meat" (Mohindra 1967, p. 489).

In 1966, RPD technicians completed the construction of the portable whole-body counting system (Bird 1968b). This specialized sensing technology's availability enabled the RPD to expand the geographical scale and reach of its direct body burden measurements in northern Canada. Following field trials and calibration tests, a team of scientists from the RPD used a chartered aircraft to transport the counter to communities across the North. Once on the ground, however, the RPD scientists relied on the local availability of snowmobiles, dogsleds, jeeps, and tractors to move the portable system between the plane and community (Tracy et al. 1997, p. 432). During an initial 1966 field survey, the RPD visited nine communities in the eastern Arctic and measured the Cesium-137 body burdens of 260 Inuit (Bird 1968b, p. 637). The following year, the RPD expanded the survey to include communities in the central and western Arctic. By 1969, RPD technicians and scientists had traveled to 41 northern communities and used the portable whole-body counter to measure the Cesium-137 body burdens of approximately 3000 northern residents (Tracy et al. 1997, p. 431). Through the 1967-1969 surveys, the RPD added important geographic detail to its assessment of northern radioactive exposures. The results, however, seemed to confirm the findings produced through the urine sampling program. Although exposure levels recorded for some individuals exceeded or approached the maximum permissible dose for Cesium-137, RPD officials concluded that average body burdens in northern Canada had not exceeded the safe limits (Tracy et al. 1997). Based on these surveys' results, the RPD suspended the northern monitoring program in 1969 (Tracy et al. 1997).

\section{Conclusion: Locating the Boundaries of the Nuclear North}

The detection of radionuclides in the bodies of caribou in northern Canada both demonstrated the global reach of nuclear fallout and revealed the unevenness of toxic relations and radioactive exposures (Masco 2015; Martin 2018; Bocking 2017; Liboiron et al. 2018). Although global monitoring programs indicated that the Arctic environments were subject to lower levels of nuclear fallout, migratory caribou herds throughout northern Canada exhibited significantly higher radioactive contamination levels than grazing animals in more southerly regions. In the early 1960s, a group of Alaskan scientists involved in the US Atomic Energy Commission's Cape Thompson bioenvironmental studies helped clarify the ecological mechanisms that facilitated radionuclides' movement through the lichen-caribou-human food chain. In doing so, their work highlighted how local ecological conditions shaped radioactive exposures. The scientific documentation of a distinct northern pathway of exposure heightened concerns among Canadian public health officials about the potential impact that nuclear fallout was having on migratory caribou and Indigenous northerners who consumed contaminated caribou meat. Between 1963 and 1969, Canada's Radiation Protection Division coordinated a "Special Northern Study," through 
which officials aimed to measure, monitor, and map radioactive exposures across the North. While the RPD emphasized its technoscientific approach to measuring radioactive exposures, the monitoring program's legitimacy was tied to establishing interdepartmental linkages within the federal bureaucracy and connections with members of the country's northern administration. In 1969, the RPD's northern monitoring program was suspended after officials determined that radioactive exposure levels had not exceeded internationally accepted threshold values.

Through its investigation of northern radioactive exposures, the RPD contributed to the production of terms by which northern Canada could be understood as a nonnuclear space. Despite increasing evidence suggesting that the lichen-caribou-human pathway of exposure amplified the bioaccumulation of radionuclides, scientists and public health officials in Canada believed that the resulting body burdens still fell within acceptable levels of exposure to radioactive material. Although average body burdens in northern communities were higher than those documented in southern Canada, the RPD believed that the threshold for radioactive exposures had not been exceeded. During the 1960s, Canada's emerging public health approach to radiation protection was influenced strongly by the increasing importance of nuclear technologies in national and international political and economic systems. In his review of Canada's radiation protection services, Peter Bird claimed that radiation exposure and the possible effects on health "is a subject the discussion of which often generates an emotional rather than an objective response" (1964a, p. 1024). After outlining steps taken by the government to protect the health of radiation workers, Bird argued that the "imposition of unnecessary and unrealistic control measures based on emotional concern about radiation effects could have a serious effect on the medical and technical development of the country" (1964a, p. 1029).

The view that radiological hazards_-including those linked to environmental radioactivity - had to be measured against the ostensible social, political, and economic benefits offered by nuclear technological development was echoed in Canada's emergent federal health policy framework. In 1961, the federal government initiated a Royal Commission on Health Services, intended to report on existing facilities and Canadians' future health requirements. In a study prepared for the Royal Commission, Robert Kohn (1967, pp. 75-76) situated radiation exposures among an increasing number of health hazards that stemmed from the anthropogenic alteration of the physical environment. Although Kohn acknowledged scientific uncertainty surrounding the biological and genetic effects of low-dose radioactive exposures, he was careful to interpret the risks in relation to the benefits derived from nuclear technologies: "Here, as with other advances of the human race, it may be unrealistic to expect that the vast benefits of nuclear energy and radiology can be reaped entirely without sacrifice, but such sacrifice must be kept to the minimum which our knowledge permits us to reach" (1967, p. 95). For Kohn, the ICRP's development of threshold values and the RPD's efforts to mitigate radioactive exposures in Canada were essential developments in national and international efforts to assess and control radiation hazards (1967, p. 93). However, as suggested by my examination of northern nuclearity's contested boundaries, the radiological risks engendered by the onset of the atomic age were distributed unevenly and shaped profoundly by local ecological relationships. 


\section{Archival Collections}

Library Archives Canada (LAC). Ottawa, Ontario.

RG 10/R216. Department of Indian Affairs.

RG 85. Northern Affairs Program.

RG 109. Canadian Wildlife Service.

\section{References}

Abraham, I. 2006. The Ambivalence of Nuclear Histories. Osiris 21 (1): 49-65.

ACHRE: Advisory Committee on Human Radiation Experiments. 1995. Final Report of the Advisory Committee on Human Radiation Experiments. Washington, D.C.: Government Printing Office. https ://bioethicsarchive.georgetown.edu/achre/ Accessed 14 Feb 2020.

Alaska Conservation Society. 1961. News Bulletin 2 (2): 1-28.

Banfield, A.W.F. 1961. A Revision of the Reindeer and Caribou, Genus Rangifer. Ottawa: National Museum of Canada, Department of Northern Affairs and National Resources.

Bird, P.M. 1964a. Radiation Protection in Canada: Part I. Canadian Medical Association Journal 90 (17): 1024-1030.

Bird, P.M. 1964b. Radiation Protection in Canada, Part II: The Role of the Radiation Protection Division in Safeguarding the Health of Radiation Workers. Canadian Medical Association Journal 90 (18): 1075-1080.

Bird, P.M. 1964c. Radiation Protection in Canada, Part III: The Role of the Radiation Protection Division in Safeguarding the Health of the Public. Canadian Medical Association Journal 90 (19): 1114-1120.

Bird, P.M. 1966. Radionuclides in Foods. Canadian Medical Association Journal 94 (12): 590-597.

Bird, P.M. 1968a. Body Burden Assay Services of the Radiation Protection Division. American Journal of Public Health and the Nation's Health 58 (12): 2261-2266.

Bird, P.M. 1968b. Studies of Fallout ${ }^{137} \mathrm{Cs}$ in the Canadian North. Archives of Environmental Health 17 (4): 631-638

Bocking, S. 1995. Ecosystems, Ecologists, and the Atom: Environmental Research at Oak Ridge National Laboratory. Journal of the History of Biology 28 (1): 1-47.

Bocking, S. 2009. A Disciplined geography: Aviation, Science, and the Cold war in Northern Canada, 1945-1960. Technology and Culture 50 (2): 265-290.

Bocking, S. 2010. Seeking the Arctic: Science and Perceptions of Northern Canada. The Dalhousie Review 90 (1): 60-74.

Bocking, S. 2013. Situated yet Mobile: Examining the Environmental History of Arctic Ecological Science. In New Natures: Joining Environmental History with Science and Technology Studies, ed. D. Jørgensen, F.A. Jørgensen, and S. Pritchard, 164-178. Pittsburgh, PA: University of Pittsburgh Press.

Bocking, S. 2017. Toxic Surprises: Contaminants and Knowledge in the Northern Environment. In Ice Blink: Navigating Northern Environmental History, ed. S. Bocking and B. Martin, 421-464. Calgary: University of Calgary Press.

Boudia, S. 2007. Global Regulation: Controlling and Accepting Radioactivity Risks. History and Technology 23 (4): 389-406.

Burch, K.A. 2019. When overflow is the Rule: The Evolution of the Transnational Nuclear Assemblage and its Technopolitical Tools for Framing Human-Radionuclide Relationality. Geoforum 107: 66-76.

Burchell, J.D., J.H. Gordon, and A.A. Downs. 1967. Cesium-137 in the Canadian North. Data from Radiation Protection Programs 4 (4): 3-13.

Cittadino, E. 2018. Barry Commoner and Paul Sears on Project Chariot: Epiphany, Ecology, and the Atomic Energy Commission. Isis 109 (4): 720-743.

Coates, K. 1994. The Rediscovery of the North: Towards a Conceptual Framework for the Study of Northern/Remote Regions. Northern Review 12 (13): 15-43.

Coates, P. 1989. Project Chariot: Alaskan Roots of Environmentalism. Alaska History 4: 1-31.

Commoner, B. 1958. The Fallout Problem. Science 127 (3305): 1023-1026. 
Cowen, D. 2020. "Following the Infrastructures of Empire: Notes on Cities, Settler Colonialism, and Method. Urban Geography 41 (4): 469-486.

Cram, S. 2016. Living in Dose: Nuclear Work and the Politics of Permissible Exposure. Public Culture 28 (80): 519-539.

Creager, A.N.H. 2014. Atomic Tracings: Radioisotopes in Biology and Medicine. In Science and Technology in the Global Cold War, ed. N. Oreskes and J. Krige. Cambridge, MA: MIT Press.

DNHW: Department of National Health and Welfare. 1955. Annual Report for the Fiscal Year Ended March 31, 1955. Ottawa: Queen's Printer and Controller of Stationary.

DNHW: Department of National Health and Welfare. 1966a. Annual Report for the Fiscal Year Ended March 31, 1965. Ottawa: Queen's Printer and Controller of Stationary.

DNHW: Department of National Health and Welfare. 1968. Annual Report for the Fiscal Year Ended March 31, 1967. Ottawa: Queen's Printer and Controller of Stationary.

DNHW: Department of National Health and Welfare. 1966-1968. Data from Radiation Protection Programs, Vols. 4-6. Ottawa: Department of National Health and Welfare.

Farish, M. 2013. The Lab and the Land: Overcoming the Arctic in Cold War Alaska. Isis 104 (1): $1-29$.

Federal Radiation Council. 1960. Report No. 1: Background Material for the Development of Radiation Protection Standards. Washington, D.C.: U.S. Department of Health, Education, and Welfare.

Finnegan, D.A. 2008. The Spatial Turn: Geographical Approaches in the History of Science. Journal of the History of Biology 41 (2): 369-388.

Gieryn, T. 1999. Cultural Boundaries of Science: Credibility on the Line. Chicago, IL: University of Chicago Press.

Gorham, E. 1959. A Comparison of Lower and Higher Plants as Accumulators of Radioactive Fall-out. Canadian Journal of Botany 37 (2): 327-329.

Hamblin, J.D. 2008. Poison in the Well: Radioactive Waste in the Oceans at the Dawn of the Nuclear Age. New Brunswick, NJ: Rutgers University Press.

Hanson, W.C. 1965a. Seasonal Cycle of ${ }^{137}$ Cs in Some Alaskan Natives and Animals. Health Physics 11: 1401-1406.

Hanson, W.C. 1966. Fallout Radionuclides in Alaskan Food Chains. American Journal of Veterinary Research 27 (116): 359-366.

Hanson, W.C., H. Palmer, and B. Griffin. 1966. Radioactivity in Northern Alaskan Eskimos and their Foods, Summer 1962. In Environment of the Cape Thompson Region, Alaska, ed. N. Wilimovsky and J. Wolfe, 1151-1164. Springfield, VA: US Atomic Energy Commission.

Hanson, W.C., and H.E. Palmer. 1965. Seasonal Cycle of ${ }^{137} \mathrm{Cs}$ in Some Alaskan Natives and Animals. Health Physics 11: 1401-1406.

Hecht, G. 2009. The Radiance of France: Nuclear Power and National Identity after World War II. Cambridge, MA: MIT Press.

Hecht, G. 2012. Being Nuclear: Africans and the Global Uranium Trade. Cambridge, MA: MIT Press.

Higuchi, T. 2018. Epistemic Frictions: Radioactive Fallout, Health Risk Assessments, and the Eisenhower Administration's Nuclear-Test Ban Policy, 1954-1958. International Relations of the Asia-Pacific 18 (1): 99-124.

ICRP: International Commission on Radiological Protection. 1959a. Recommendations of the International Commission on Radiological Protection, Adopted September 8, 1958. Annals of the ICRP Publication 1 (1): 1-18.

ICRP: International Commission on Radiological Protection. 1959b. Recommendations of the International Commission on Radiological Protection, ICRP Publication 2: Report of Committee II on Permissible Dose for Internal Radiation. Oxford: Pergamon Press.

Kaplan, Lawrence. n.d. "Inuit or Eskimo: Which Name to Use." Fairbanks: University of Alaska, Alaska Native Language Center. www.uaf.edu/anlc/resources/inuit_or_eskimo.php. Accessed 1 August 2020.

Kelsall, J.P. 1957. Continued Barren-Ground Caribou Studies. Wildlife Management Bulletin, Ser. 1, no. 12. Ottawa: Canadian Wildlife Service.

Kelsall, J.P. 1968. The Migratory Barren-Ground Caribou of Canada. Ottawa: Queen's Printer.

Kirsch, S. 2000. Peaceful Nuclear Explosions and the Geography of Scientific Authority. The Professional Geographer 52 (2): 179-192.

Kirsch, S. 1998. Experiments in Progress: Edward Teller's Controversial Geographies. Ecumene 5 (3): 267-285. 
Kirsch, S. 2005. Proving Grounds: Project Plowshare and the Unrealized Dream of Nuclear Earthmoving. New Brunswick, NJ: Rutgers University Press.

Kohn, R. 1967. The Health of the Canadian People. Ottawa: Queen's Printer.

Kulchyski, P., and F.J. Tester. 2007. Kiumajut (Talking Back): Game Management and Inuit Rights, 1950-70. Vancouver: University of British Columbia Press.

Liboiron, M., M. Tironi, and N. Calvillo. 2018. Toxic Politics: Acting in a Permanently Polluted World. Social Studies of Science 48 (3): 331-349.

Liden, K. 1961. Cesium 137 Burdens in Swedish Laplanders and Reindeer. Acta Radiologica 56 (3): 237-240.

Livingstone, D.N. 2010. Putting Science in its Place: Geographies of Scientific Knowledge. Chicago, IL: University of Chicago Press.

Martin, L. 2018. Proving Grounds: Ecological Fieldwork in the Pacific and the Materialization of Ecosystems. Environmental History 23 (3): 567-592.

Martin, A., and S. Harbinson. 1979. Introduction to Radiation Protection. London: Chapman and Hall.

Masco, J. 2015. The Age of Fallout. History of the Present 5 (2): 137-168.

Millar, S, Mitchell, D. 1998. Spectacular Failure, Contested Success: The Project Chariot Bioenvironmental Programme. Ecumene 5 (3): 287-302.

Mohindra, V.K. 1967. Cesium 137 Burdens in the Canadian North. Acta Radiologica: Therapy, Physics, Biology 6: 481-490.

Mohindra, V.K., J.H. Gordon, and A.A. Downs. 1966. Cesium-137 in the Canadian North, 1965. Data from Radiation Protection Programs 4 (4): 3-19.

Monteith, J.W. 1959. Canada's Program of Radiation Protection. Canadian Journal of Public Health / Revue Canadienne de Santé Publique 50 (9): 355-359.

O'Neill, D. 2007. The Firecracker Boys: H-Bombs, Inupiat Eskimos, and the Roots of the Environmental Movement. Philadelphia, PA: Basic Books.

Overton, T.R., and M.R. Quastel. 1967. Absorption and Excretion of 137 Cs by Humans. Radiation Research 31 (3): 540.

Palmer, H.E., W.C. Hanson, B.I. Griffin, and W.C. Roesch. 1963. Cesium-137 in Alaskan Eskimos. Science 142 (3588): 64-66.

Pavlovski, O.A. 1998. Radiological Consequences of Nuclear Testing for the Population of the Former USSR (Input Information, Models, Dose, and Risk Estimates). In Atmospheric Nuclear Tests: Environmental and Human Consequences, ed. C.S. Shapiro, 219-260. Berlin: Springer.

Pitkanen, L., and M. Farish. 2018. Nuclear Landscapes. Progress in Human Geography 42 (6): 862-880.

Pochin, E. 1983. Nuclear Radiation: Risks and Benefits. Oxford: Clarendon Press.

Power, E., and A. Keeling. 2018. Cleaning Up Cosmos: Satellite Debris, Radioactive Risk, and the Politics of Knowledge in Operation Morning Light. Northern Review 48: 81-109.

Pruitt, W.O. 1962. A New Caribou Problem. The Beaver (December): 24-25.

Pruitt, W.O. 1966. Ecology of Terrestrial Mammals. In Environment of the Cape Thompson Region, Alaska, ed. N. Wilimovsky and J. Wolfe, 519-564. Springfield, VA: US Atomic Energy Commission.

Samuels, E.R. 1967. Strontium-90 in Human Bone, 1964-1965, with Preliminary Results from 1966. Data from Radiation Protection Programs 5 (3): 3-6.

Samuels, E.R. 1968. Strontium-90 in Human Bone, 1966-1967. Data from Radiation Protection Programs 6 (2): 3-26.

Sandlos, J. 2007. Hunters at the Margin: Native People and Wildlife Conservation in the Northwest Territories. Vancouver: University of British Columbia Press.

Sheen, E.M. 1964. Gamma Spectrometer for Use in Whole Body Counting. Richland, WA: Hanford Atomic Products Operation.

Smith, C.L. 1965. Radiation Hazard to Man and Animals from Fallout in the Arctic. Polar Record 12 (81): 709-716.

Stephens, S. 2002. Bounding Uncertainty: The Post-Chernobyl Culture of Radiation Protection Experts. In Culture and Catastrophe: The Anthropology of Disaster, ed. S. Hoffman and A. Oliver-Smith. 91-112. Santa Fe, NM: School of American Research Press.

Tracy, B.L., G.H. Kramer, J.M. Zielinski, and H. Jiang. 1997. Radiocesium Body Burdens in Residents of Northern Canada from 1963-1990. Health Physics 72 (3): 431-442. 
UNSCEAR: United Nations Scientific Committee on the Effects of Atomic Radiation. 1958. Report of the United Nations Scientific Committee on the Effects of Atomic Radiation. General Assembly Official Records: Thirteenth Session supplement 17 (A/3838). New York: United Nations.

US Department of State. 1963. Treaty Banning Nuclear Weapon Tests in the Atmosphere, in Outer Space and Under Water. Signed at Moscow August 5, 1963, Entered into Force October 10, 1963. http://https://www.state.gov/t/isn/4797.htm\#treaty. Accessed 30 March 2017.

Walker, J.S. 2000. Permissible Dose: A History of Radiation Protection in the Twentieth Century. Berkeley, CA: University of California Press.

Willimovsky, N.J., and J. Wolfe, eds. 1966. Environment of Cape Thompson Region, Alaska. Springfield, VA: US Atomic Energy Commission, Division of Technical Information, PNE-481.

Wilson, C. 1967. Cold Regions Science and Engineering, Part 1: Environment; Section A3: Climatology: Radioactive Fallout in Northern Regions. Hanover, NH: Cold Regions Research and Engineering Laboratory.

Wright, S., B. Howard, P. Strand, T. Nylén, and M. Sickel. 1999. Prediction of 137 Cs Deposition from Atmospheric Nuclear Weapons Tests within the Arctic. Environmental Pollution 104 (1): 131-143.

Publisher's Note Springer Nature remains neutral with regard to jurisdictional claims in published maps and institutional affiliations. 